\title{
Quality Enhancement of Humid Tropical Soils after Application of Water Hyacinth (Eichornia crassipes) Compost
}

\author{
Z. Muktamar*, B. Justisia and N. Setyowati \\ Soil Science Department, University of Bengkulu, Bengkulu 38371, Indonesia
}

Muktamar Z., Justisia B., and Setyowati N. (2016). Quality Enhancement of Humid Tropical Soils after Application of Water Hyacinth (Eichornia crassipes) Compost. Journal of Agricultural Technology 12(7.1):1209-1225.

Compost application to soil leads to the improvement of its properties. However, nutrient content and enhancing capacity of compost are highly dependent on the original source and additive. The purpose of the experiment was to investigate selected soil quality indicators' improvement and sweet corn growth following application of water hyacinth compost. Greenhouse experiment was carried out using Completely Randomized Design with 2 factors. First factor consisted of soils from humid tropics, i.e. Andepts, Udepts, and Udults and second factor comprised of water hyacinth compost rates, i.e. $0,5,10,15,20$, and $25 \mathrm{Mg} \mathrm{ha}{ }^{-1}$. Treatment combinations were replicated 3 times. Compost was incorporated in soil a week before planting of sweet corn. After reaching maximum sweet corn growth, soil sample was collected, air-dried, grinded and passed through $0.5 \mathrm{~mm}$ screen, and analyzed for selected soil properties, except microbial biomass carbon (MBC) and particulate organic matter carbon (POMC) which were analyzed using fresh soil samples. The experiment pointed out that application of water hyacinth compost on Udepts exhibited the highest total soil organic carbon (TSOC), MBC, soil pH and available P (Bray I), followed by those in Andeps and Udults. Particulate organic matter carbon (PMOC), however, was highest in Andepts as compared to other soils. Higher rates of compost application contributed higher increase in TSOC, MBC, soil $\mathrm{pH}$, available $\mathrm{P}$, and exchangeable $\mathrm{K}$. Udults had more pronounced increase in soil $\mathrm{pH}$ and decline of exchangeable Al than other soils. Pearson correlation analysis showed that the most distinct correlation among soil properties was observed between exchangeable $\mathrm{Al}$ and soil $\mathrm{pH}$, followed by TSOC and MBC with coefficient correlation of -0.91 and 0.85 , respectively. Correlation between soil properties and sweet corn growth exhibited that the most prominent correlation was shown between available $\mathrm{P}$ and shoot dry weigh of sweet corn with coefficient correlation of 0.92 . This indicates that soil available $\mathrm{P}$ has significant contribution on sweet corn growth.

Keywords: water hyacinth compost, Eichornia crassipes, humid tropical soil, Andepts, Udults

\section{Introduction}

Organic farming system is an alternative solution of soil degradation due

Coressponding Author: Muktamar Z. E-mail address: muktamar1959@yahoo.com 
to over-use and prolong application of synthetic agrochemicals usually practiced in conventional system. This organic farming practice takes benefit mostly from organic fertilizer for its nutrient availability. A number of researchers have reported that use of organic fertilizer has enhanced soil quality. However, the benefit of organic fertilizer is highly dependent on its original sources. Lim et al. (2010) concluded that different source of compost had to be taken into consideration for its application guidelines. Hose et al. (2012) also reported that farmyard compost had $26 \%$ organic content, $8667 \mathrm{mg} \mathrm{kg}^{-1}$ nitrogen $(\mathrm{N}), 2033 \mathrm{mg} \mathrm{kg}^{-1}$ phosphorus $(\mathrm{P}), 4900 \mathrm{mg} \mathrm{kg}^{-1}$ potassium $(\mathrm{K})$ and $\mathrm{C} / \mathrm{N}$ ratio of 16.6. Another researcher pointed out that municipal waste compost had 32.9\%, $7900 \mathrm{mg} \mathrm{kg}^{-1} \mathrm{P}, 16000 \mathrm{mg} \mathrm{kg}^{-1} \mathrm{~K}, 95000 \mathrm{mg} \mathrm{kg}^{-1}$ calcium (Ca) (de Varennes et al., 2012).

Compost and vermicompost provide significant improvement on soil quality. Dairy manure compost has significant increase in soil quality as indicated by organic matter content, $\mathrm{pH}$ and Electrical Conductivity (EC), concentration of nitrate nitrogen $\left(\mathrm{NO}_{3}-\mathrm{N}\right)$, phosphorus $(\mathrm{P})$, and exchangeable potassium (K) of Alfisol from Texas USA (Butler et al. 2009). Other study also points out that application of poultry manure in conservation tillage increases soil organic carbon (SOC) and total nitrogen $(\mathrm{N})$ as well as soil enzymes at surface soil (Mankolo et al., 2012). Compost and vermicompost also significantly increase $\mathrm{SOC}$, total $\mathrm{N}$, soil $\mathrm{pH}, \mathrm{EC}$ and reduce bulk density of soil (Jouquet et al., 2011; Arthur et al. 2012). Vermicompost combined with liquid organic fertilizer also provides distinct increase in $\mathrm{NO}_{3}-\mathrm{N}$, available $\mathrm{P}$, exchangeable $\mathrm{K}$, soil $\mathrm{pH}$ and reduction of exchangeable Al to the depth of 20$25 \mathrm{~cm}$ depth of soil, but P (Muktamar et al. 2015).

Compost from weed is also reported to bring about enhancement of soil quality and plant growth. Previous study carried out by Wahyudi et al. (2010) exhibited that application of tithonia and gliricidia compost on Ultisol provided significant increase in soil $\mathrm{pH}$ and reduction of exchangeable aluminum (Al). Another study revealed that content of $\mathrm{SOC}, \mathrm{Ca}, \mathrm{Mg}, \mathrm{K}$ and total $\mathrm{N}$ of soil fertilized with cromolaena compost was higher than that of cattle manure (Suntoro et al., 2001). Improvement of soil quality after application of weed compost often leads to increase growth and yield of crop. Previous studies indicated that application of Wedelia, Tithonia, and Cromolaena compost increased growth and yield of crops (Setyowati et al. 2008; Iqua and Huasi, 2009; Setyowati et al., 2014) and could substitute for synthetic fertilizer in crop production (Setyowati et al. 2015; Muktamar et al. 2016).

Water hyacinth is another alternative for compost material. Such weed dry matter contains $22.99 \%$ protein, $0.14 \% \mathrm{Ca}, 0.6 \% \mathrm{P}, 2.3 \% \mathrm{~N}$, and $4.2 \%$ ash (Suntoro et al., 2001). Another researcher points out that water hyacinth dry 
matter has $1.5 \% \mathrm{~N}, 0.74 \% \mathrm{P}, 5.7 \% \mathrm{~K}$ (Vidya and Girish, 2014). Water hyacinth compost application is reported to enhance growth and yield of tomato (Mashavira et al., 2015), coriander (Coriandrum sativum) (Lata and Dubey, 2013), spinach (Sanni and Adesina, 2012), green mustard (Lata and Veebapani, 2011), and cabbage (Mashavira, 2014). Application of compost of water hyacinth does not have an effect on yield corn even though improves its growth (Osoro et al., 2014).

The purpose of the experiment was to investigate selected soil quality indicators' improvement and sweet corn growth following application of water hyacinth compost.

\section{Materials and methods}

\section{Experimental Design and Compost Preparation}

Greenhouse experiment was conducted from September 2015 to February 2016, arranging in Completely Randomized Design (CRD) with 2 factors. First factors were three soil types, i.e. Andepts, Udepts, and Udults and second factors were rates of water hyacinth compost, i.e. $0,5,10,15,20$, and $25 \mathrm{Mg}$ $\mathrm{ha}^{-1}$. Treatment combination was replicated 3 times.

Water hyacinth compost was prepared by mixing of leaves and Effective Microorganism (EM-4). The EM-4 solution was a mixture of $50 \mathrm{ml}$ EM4 and $10 \mathrm{~g}$ sugar in $2000 \mathrm{ml}$ aquadest. Approximately $100 \mathrm{~kg}$ of water hyacinth leaves were sliced into $5 \mathrm{~cm}$ long and placed in $2 \times 2 \times 0.5 \mathrm{~m}^{3}$ wooden box, thereafter was sprayed with EM-4 solution. The mixture was covered with plastic and incubated for 70 days. The mixture was reversed every week and watered when required. After incubation, the compost was sieved with $2 \mathrm{~mm}$ screen and it was ready for application. Water hyacinth compost had $27.2 \%$ organic-C, $2.16 \%$ $\mathrm{N}, 1.71 \% \mathrm{P}, 1.09 \% \mathrm{~K}$, and ph of 7.9 .

\section{Soil Collection and Treatment Preparation}

Soil samples were collected from three different sites, representing different altitudes. Each soil had different characteristics. First soil sample was Andepts from Air Duku Village, Rejang Lebong District located at latitude $3^{\circ}$ $27^{\prime} 34.26 " \mathrm{~S}$ and longitude $102^{\circ} 36^{\prime} 54.95$ " at elevation of $1054 \mathrm{~m}$ above sea level. The soil in the site has continuously been cropped to organic vegetables since 2011. Each season soil was fertilized with $15 \mathrm{Mg} \mathrm{ha}^{-1}$ organic fertilizer and no additional synthetic fertilizer was applied. Andepts surface soil contained $24.0 \mathrm{~g} \mathrm{~kg}^{-1}$ TSOC, $16.02 \mathrm{mg} \mathrm{kg}^{-1}$ available $\mathrm{P}, 241.8 \mathrm{mg} \mathrm{kg}^{-1}$ 
exchangeable $\mathrm{K}, 1.46 \mathrm{~g} \mathrm{~kg}^{-1} \mathrm{MBC}, 0.51 \mathrm{~g} \mathrm{~kg}^{-1}$ POMC, $14.1 \mathrm{mg} \mathrm{kg} \mathrm{kg}^{-1}$ exchangeable $\mathrm{Al}$ and soil $\mathrm{pH}$ of 5.2.

Second soil sample was Udepts from Tebat Monok Village, Kepahiang District located at latitude $3^{\circ} 39^{\prime} 16.1^{\prime \prime} \mathrm{S}$ and longitude $102^{\circ} 34^{\prime} 26.9^{\prime \prime} \mathrm{E}$ at elevation of $519 \mathrm{~m}$ above sea level. The soil in the site was fertilized with coffee bean compost at rate of $40 \mathrm{Mg} \mathrm{ha}^{-1}$ for two seasons before soil sample was collected. Udepts surface soil had $24.7 \mathrm{~g} \mathrm{~kg}^{-1}$ TSOC, $59.79 \mathrm{mg} \mathrm{kg}$ available P, $70.2 \mathrm{mg} \mathrm{kg}^{-1}$ exchangeable $\mathrm{K}, 2.93 \mathrm{~g} \mathrm{~kg}^{-1} \mathrm{MBC}, 0.52 \mathrm{~g} \mathrm{~kg}^{-1}$ POMC, $36.0 \mathrm{mg} \mathrm{kg}^{-1}$ exchangeable $\mathrm{Al}$ and soil $\mathrm{pH}$ of 5.6.

The third soil sample was Udults from Kandang Limun Village, Bengkulu City located at latitude $3^{\circ} 45^{\prime} 10.9{ }^{\prime \prime} \mathrm{S}$ and longitude $102^{\circ} 17^{\prime} 0.20 ” \mathrm{E}$ at elevation of $15 \mathrm{~m}$ above sea level. Site was a bare soil dominated with reed weed for more than a year. Udults surface soil contained $24.0 \mathrm{~g} \mathrm{~kg}^{-1} \mathrm{TSOC}$, $9.96 \mathrm{mg} \mathrm{kg}^{-1}$ available $\mathrm{P}, 66.3 \mathrm{mg} \mathrm{kg}^{-1}$ exchangeable $\mathrm{K}, 1.46 \mathrm{~g} \mathrm{~kg}^{-1} \mathrm{MBC}, 0.40$ $\mathrm{g} \mathrm{kg}^{-1}$ POMC, $113 \mathrm{mg} \mathrm{kg}^{-1}$ exchangeable $\mathrm{Al}$ and soil $\mathrm{pH}$ of 4.50 .

Composite soil sample at depth of $0-20 \mathrm{~cm}$ was collected from each site, afterward air-dried and sieved with $5 \mathrm{~mm}$ screen. Ten $\mathrm{kg}$ of soil was incorporated with water hyacinth compost corresponding to each treatment and put into polybag. The mixture was incubated for one week and kept moist by watering when required.

\section{Greenhouse Experiment}

After a week of soil and compost incorporation, 2 sweet corn seeds were planted to each polybag, thinning to only one healthier plant after one week of planting. No additional synthetic fertilizer was applied, leading to only take benefit of the compost for nutrient availability to plant. The growing media was watered every day to keep soil in moist condition. The experiment ended when maximum growth of sweet corn was achieved. Sweet corn plant was cut after plant height was measured. The shoot, then, was dried at $65-70^{\circ} \mathrm{C}$ for 2 days and weighed for shoot dry weight.

Fresh soil sample was analyzed for MBC by fumigation- titration method and POMC by physical fractionation (Cambardella and Elliot, 1992). Remaining soil was air-dried, sieved with $0.5 \mathrm{~mm}$ screen and analyzed for TSOC (Walky and Black), exchangeable Al (neutral salt extraction by Thomas, 1982), available P (Bray I), exchangeable K (ammonium acetate extraction and flame photometer), and soil $\mathrm{pH}$ (electrometric using $\mathrm{pH}$ meter at water and soil ratio of $1: 1$ by weight). 


\section{Statistical Analysis}

Data were subjected to analysis of variance using PROC GLM in Statistical Analysis System version 9.1 .3 portable at $\mathrm{P}<0.05$. Soil types differences was separated using Duncan's Multiple Range Test and LOF treatment means were compared using orthogonal polynomial at probability level of 0.05 .

\section{Results and Discussion}

Application of water hyacinth compost had significant effect on soil quality indicator and growth of sweet corn as indicated in Table 1 but water hyacinth compost had no significant effect on POMC. Distinct difference of soil quality was also observed among three soils used in the experiment. The difference was mainly associated with inherent characteristics of each soil. First soil (Andepts) was collected from area with high influence of volcano activities and cropped to organic vegetables crops since 2011. Second soil (Udepts) was intensively managed and had been fertilized with high rate of organic fertilizer, while the third soil (Udults) was relatively unfertile soil.

Table 1. Analysis of variance for soil properties and growth of sweet corn.

\begin{tabular}{lccc}
\hline \multicolumn{1}{c}{ Variables } & Soil & $\begin{array}{c}\text { Probability F }<0.050 \\
\text { Compost }\end{array}$ & Interaction \\
\hline Total Soil Organic Carbon & $<0.0001$ & $<0.0001$ & $<0.0001$ \\
Particulate Organic Microbial & 0.0097 & 0.8580 & 0.9646 \\
Carbon & & & \\
Microbial Biomass Carbon & 0.0089 & 0.0420 & 0.9989 \\
Exchangeable Al & $<0.0001$ & 0.0030 & 0.0125 \\
Soil pH & $<0.0001$ & $<0.0001$ & $<0.0001$ \\
Available P (P-Bray I) & $<0.0001$ & $<0.0001$ & 0.0061 \\
Exchangeable K & $<0.0001$ & 0.0029 & 0.1685 \\
Plant Height & $<0.0001$ & 0.0015 & 0.3315 \\
Shoot Dry Weight & $<0.0001$ & 0.0001 & 0.2012 \\
\hline
\end{tabular}

\section{Effect of water hyacinth compost on soil quality}

The experiment showed that Udepts had highest TSOC, followed by Andepts and Udults (Figure 1). This was somehow related to high application of coffee bean compost at rate of $40 \mathrm{Mg} \mathrm{ha}^{-1}$ for the last two seasons before soil collection, leading to high concentration of organic carbon in soil. Study by Pujianto (2007) pointed out that coffee waste had high organic carbon, CEC, water retention, and phosphorus. Meanwile, Andepts was cropped to organic 
vegetable since 2011 with fertilization of vermicompost at rate of $15 \mathrm{Mg} \mathrm{ha}^{-1}$ each season while Udults was from site dominated with reed weed for more than a year. Ultisol inherently has low soil organic carbon (Adijaya and Made, 2014). When compared to initial content, only did Udepts have higher TSOC with application of water hyacinth compost, indicating that decomposition of organic matter was lower than that of addition, while the other two soils exhibited vice versa.

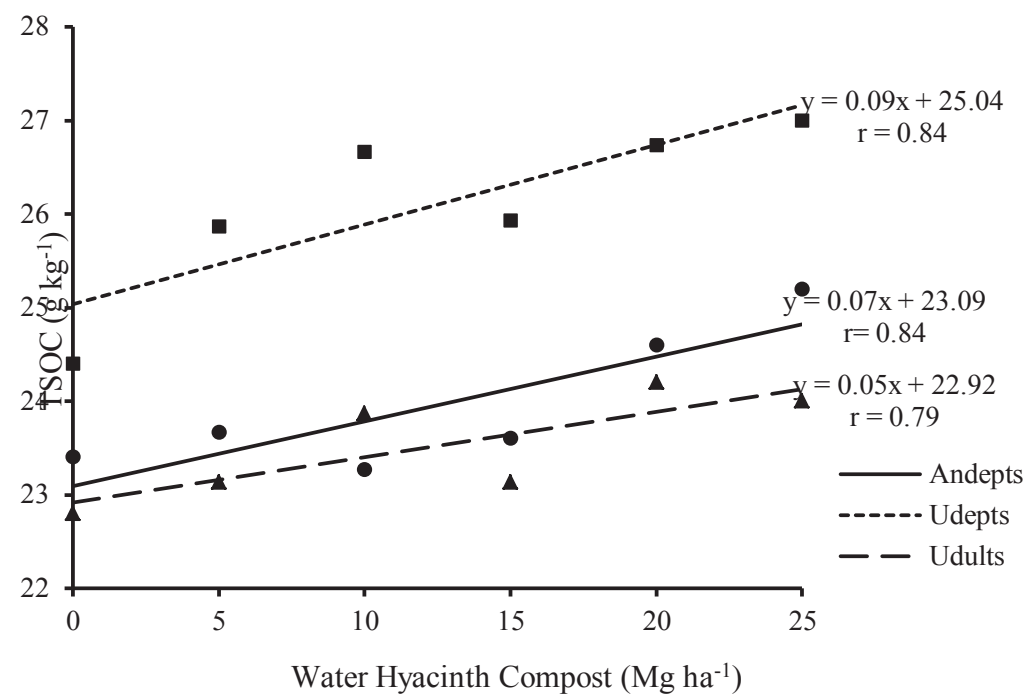

Figure 1. Total soil organic carbon of tropical soils as affected by water hyacinth compost

Higher rates of water hyacinth compost application resulted consistently linear increase in TSOC for all soils, with $\mathrm{r} 0.79$ or higher (Figure 1), even though each soil had different increment as indicated from slopes of graph lines. Total soil organic carbon increased by $7.7 \%, 10.7 \%$, and $5.3 \%$ for Andepts, Udepts, and Udults, respectively, when soil was fertilized with particular compost at rate of $25 \mathrm{Mg} \mathrm{ha}^{-1}$ as compared to that of control. The result was correspond to that concluded by Khan and Sanwar (2002) where addition of water hyacinth compost on loamy soil increased soil organic carbon and CEC. 


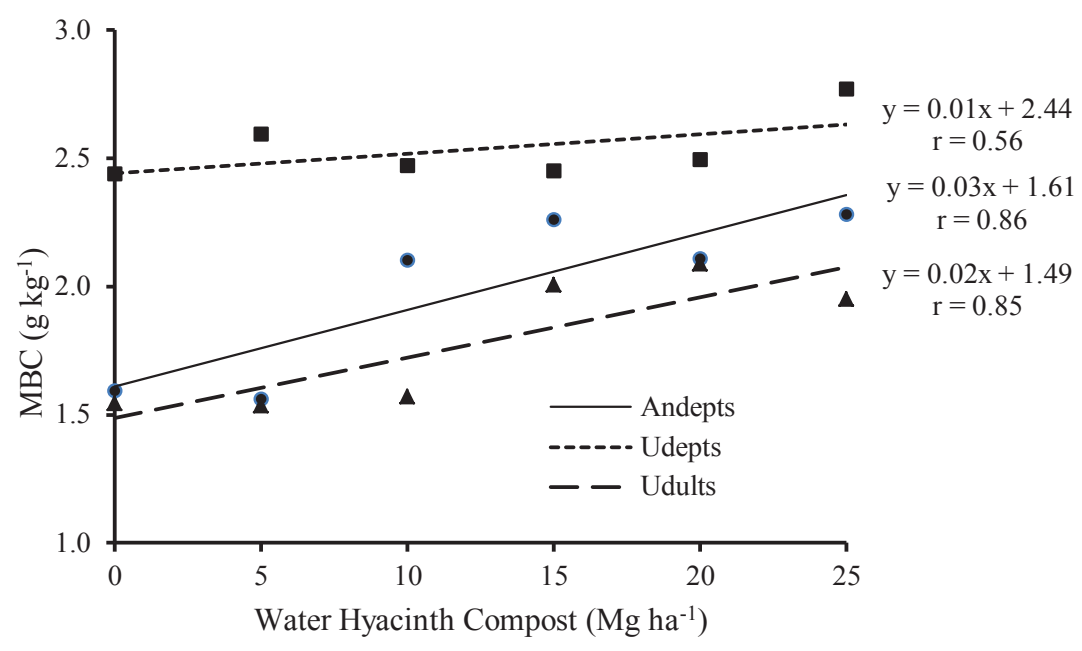

Figure 2. Microbial Biomass Carbon (BMC) of Andepts, Udepts, and Udults as influenced by water hyacinth compost

Similar trend was observed for biomass microbial carbon where water hyacinth compost application up to rate of $25 \mathrm{Mg} \mathrm{ha}^{-1}$ linearly increased MBC of soil (Figure 2). The trend was similar to that TSOC, indicating that MBC was mainly associated with soil organic carbon content in soil as also concluded by Liu et al. (2013) that MBC raised with increasing soil organic carbon. As TSOC, Udepts had highest MBC, followed by Andepts and Udults; however, Andepts and Udults have better response to the application of water hyacinth compost than Udepts. This finding indicates that soil with low content of TSOC leads to higher increment of MBC with increasing application of particular compost. Baaru et al. (2007) also reported that incorporation of organic resources to soil had distinct increase in MBC as compared to control. The portion of $\mathrm{MBC}$ in the soil organic carbon varied from $6.7 \%$ to $10.3 \%$ which was higher than that reported by Ananyeva et al. (2009) where the portion of $\mathrm{MBC}$ in forest soil ranged from $1.3 \%$ to $5.4 \%$. In addition, higher increase of MBC portion was observed at lower content of TSOC.

Application of water hyacinth compost did not significantly influence POMC of soil, but soil types did (Figure 3). Unlike MBC, Andepts contained highest POMC followed by Udepts and Udults. High content of POMC in Andepts might be associated with that Andepts was cropped to organic vegetables for more than 6 years (Muktamar et al. 2016) at $1054 \mathrm{~m}$ above sea level. Cambardella and Elliot (1992) pointed out that elevation and land slope 
had effect on POMC. On the other hand, Udults was collected from fallow site dominated with reed weed at elevation of $15 \mathrm{~m}$ above sea level. Figure 3 also showed that water hyacinth compost had no distinct effect on POMC. Liu et al. (2013) observed different result where long term effect of manure had significant increase in POMC.

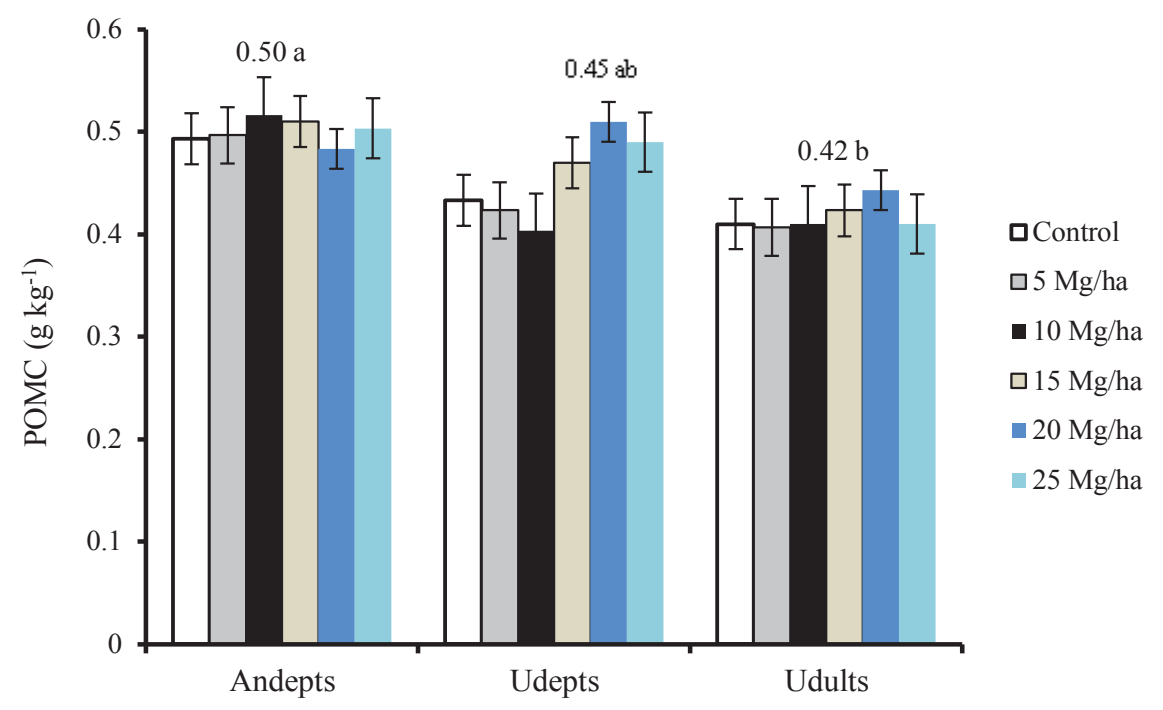

Figure 3. Particulate organic matter carbon (POMC) of Andepts, Udepts, and Udults under different rates of hyacinth compost.

Application of water hyacinth compost up to the rate of $25 \mathrm{Mg} \mathrm{ha}^{-1}$ linearly reduced exchangeable $\mathrm{Al}$ and soils studied in the experiment had significant differences of exchangeable $\mathrm{Al}$ as indicated in Figure 4. Moreover, Udult had greatest exchangeable Al, followed by Udepts and Andepts. Udults was naturally acid soil with high exchangeable $\mathrm{Al}\left(113 \mathrm{mg} \mathrm{kg}^{-1}\right)$ and low $\mathrm{pH}$ (4.5) while the other two soils had low Al saturation. Reduction of exchangeable $\mathrm{Al}$ due to application of compost was related to soil organic content as shown in Figure 1, 2, and 3. Humic substance released during mineralization of soil organic material contains active functional groups such as carboxyl and phenolic groups, leading to formation of organo-metalic complex (Spark, 2003), such as Al, causing lower exchangeable Al in soil. Previous study concluded that addition of humic substance extracted from organic material pronouncedly reduced Al concentration in soil (Winarso et al., 2010; 
Ifansyah, 2013). Other study also resulted in decreasing exchangeable Al when acid soil was treated with citric and oxalic acid (Muktamar et al. 1998).

Reduction of exchangeable $\mathrm{Al}$ in relation to increasing rate of water hyacinth compost is more pronounced for Udults as compared to Andepts and Udepts, as indicated from slope of graph line in Figure 4. Application of compost at rate $25 \mathrm{Mg} \mathrm{ha}^{-1}$ declines $272.1 \%$ exchangeable $\mathrm{Al}$ for Udults as compared to control as well as $100 \%$ and $102.9 \%$ for Andepts and Udepts, respectively. This indicates that Udults, which is inherently acid, is more responsive to addition of compost than other two soils. This result is in concurrent to that reported by Opala et al. (2012) where addition of tithonia reduced $264.7 \%$ exchangeable $\mathrm{Al}$ as compared to control.

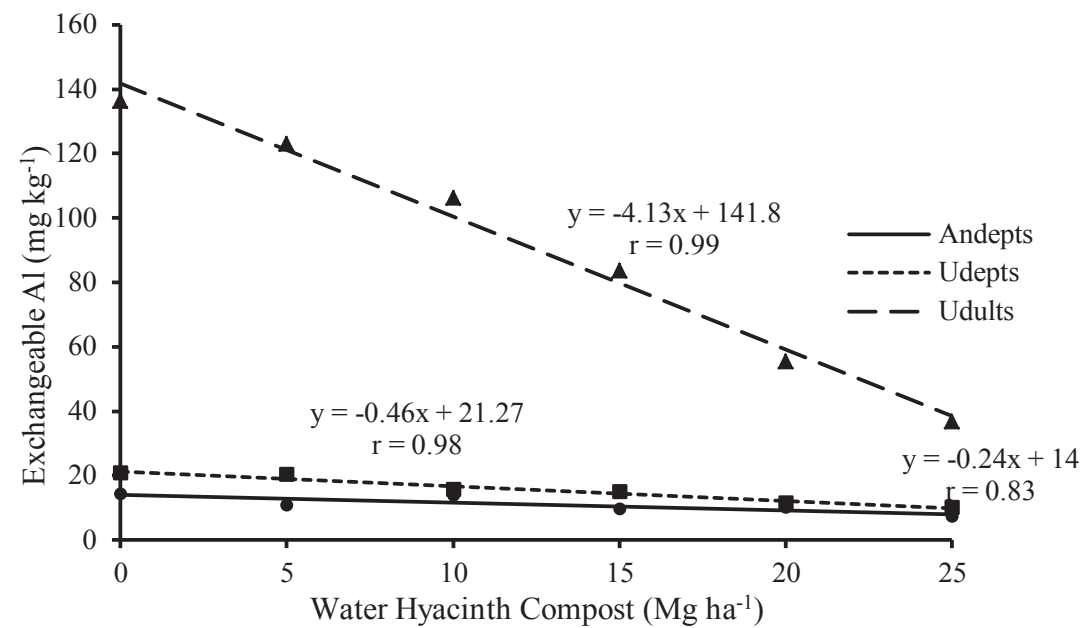

Figure 4. Effect of water hyacinth compost on exchangeable Al of Andepts, Udepts, and Udults

Reduction of exchangeable $\mathrm{Al}$ as water hyacinth compost rate increases was followed by improvement of soil pH (Figure 5). Formation of complex Alhumic substance leads to lower hydrogen production from Al hydrolysis in soil, thereafter increasing soil $\mathrm{pH}$. Previous studies pointed out that application of organic fertilizer raised soil pH (Muktamar, 1998; Valarini et al. 2009). In addition, Udepts had greatest soil $\mathrm{pH}$ followed by Andepts and Udults. However, Increment of soil $\mathrm{pH}$ is highest for Udults, suggesting that this soil is highly responsive to increasing rates of compost. Soil $\mathrm{pH}$ of Udults increases by $27.59 \%$ as rate of compost increase from control to $25 \mathrm{Mg}^{-1}$ while Andepts and Udepts are only 11.80 and $5.73 \%$, respectively. 


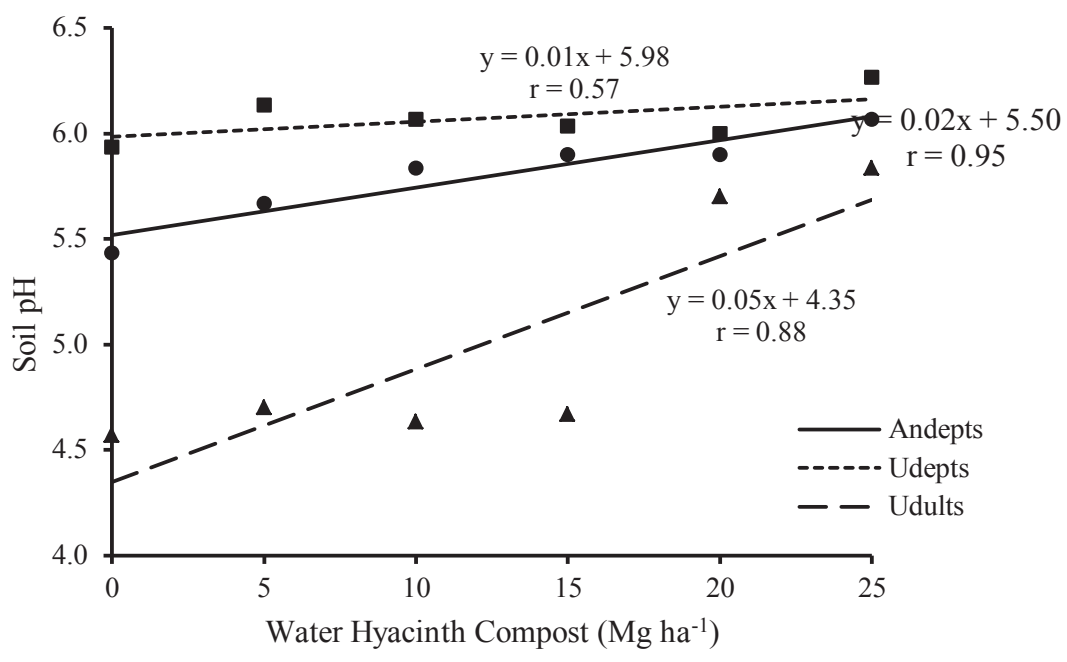

Figure 5. Soil pH of Andepts, Udepts, and Udults under different rates of water hyacinth compost.

Figures 6 and 7 indicated that application of water hyacinth compost exhibited significant increase in available $\mathrm{P}$ and exchangeable $\mathrm{K}$ for all soils studied in the experiment. However, Udults showed highest increment of available $\mathrm{P}$ and exchangeable $\mathrm{K}$ as rates of compost raise. Upon decomposition, compost releases macro and micro nutrient such as $\mathrm{P}$ and $\mathrm{K}$. In addition, as compost application rate increased, available $\mathrm{P}$ and exchangeable $\mathrm{K}$ also increased. Earlier study suggested that application of municipal compost linearly increased available $\mathrm{P}$ on calcareous soil (Hosseinpur et al., 2012). Another study carried out by Liu et al. (2013) resulted increase in available N, $\mathrm{P}$, and $\mathrm{K}$ content in soil treated with composted pineapple residue return. 


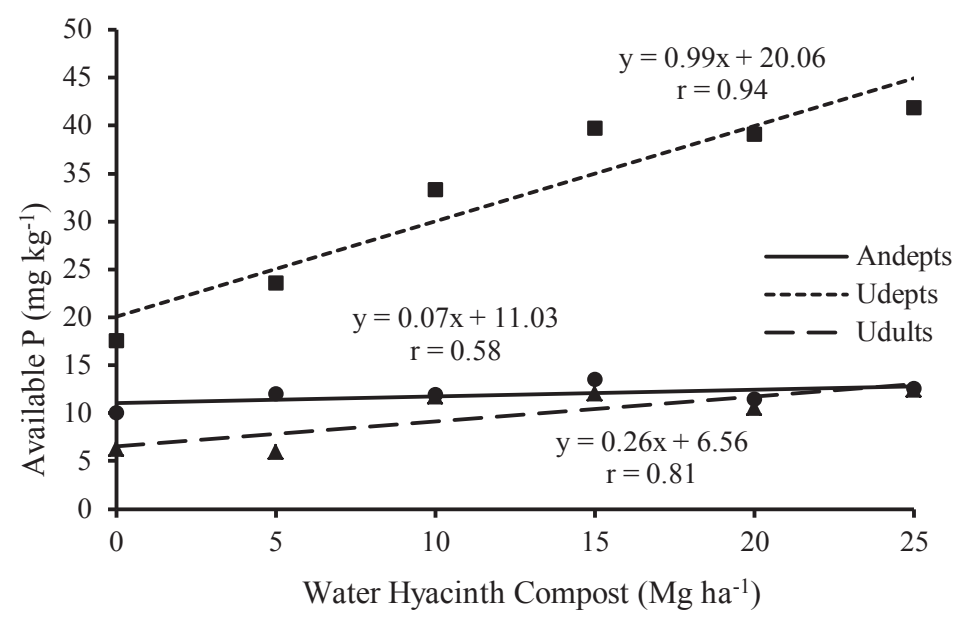

Figure 6. Soil available P in Andept, Udepts, and Udults as influenced by application of water hyacinth compost.

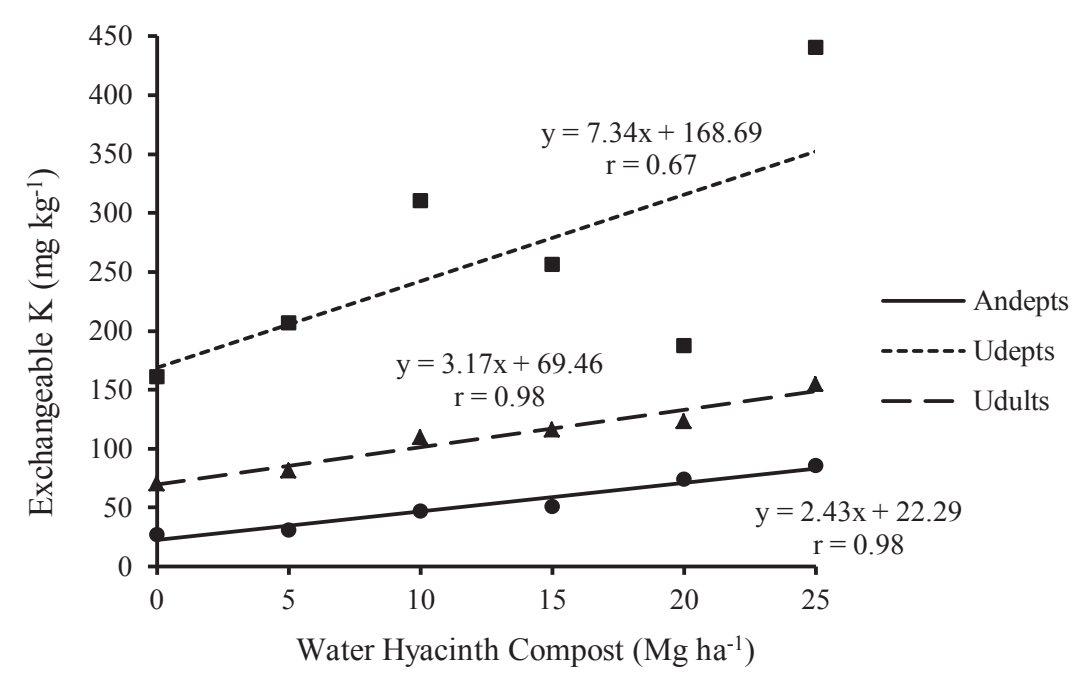

Figure 7. Effect of water hyacinth compost on exchangeable $\mathrm{K}$ in Andepts, Udepts and Udults 
Figures 6 and 7 also showed that Udepts had greatest increment of available $\mathrm{P}$ and exchangeable $\mathrm{K}$ as compared to the other soils. This phenomenon is different from other soil properties determined in this experiment. Udults has very good response on $\mathrm{BMC}$, exchangeable $\mathrm{Al}$, and soil $\mathrm{pH}$ to application of water hyacinth compost. This might be associated with low fertility of this soil as indicated by high exchangeable $\mathrm{Al}$ and low soil $\mathrm{pH}$. In term of $\mathrm{P}$ available $\mathrm{P}$ and exchangeable $\mathrm{K}$, higher content of TSOC leads to higher $\mathrm{P}$ and $\mathrm{K}$ release during its mineralization.

Application of water hyacinth compost provides enhancement of soil quality as indicated by increase in TSOC, $\mathrm{MBC}$, soil $\mathrm{pH}$, available $\mathrm{P}$, exchangeable $\mathrm{K}$ and reduction of exchangeable Al. A number of researchers concluded that soil organic carbon, microbial biomass carbon and microbial biomass nitrogen were often used as soil quality indicators (Islam and Weil, 2000; Ochiai et al., 2008; Adeboye et al., 2011; Amighi et al., 2013). This indicated that application of water hyacinth compost was also capable to increase soil quality.

Pearson correlation shows that most soil properties examined in the experiment has correlation to each other, but POMC (Table 2). The most distinct correlation among soil properties was observed between exchangeable $\mathrm{Al}$ and soil $\mathrm{pH}$ with coefficient correlation of -0.91 . High negative correlation between exchangeable $\mathrm{Al}$ and soil $\mathrm{pH}$ suggests that high $\mathrm{Al}$ hydrolysis in soil roots to increase in hydrogen concentration contributing to lower soil $\mathrm{pH}$. The second prominent correlation among soil properties is MBC and TSOC with coefficient correlation of 0.85 . Significant correlation between MBC and TSOC indicates that concentration of TSOC in soil plays extremely important role in enhancing activity of soil microorganism.

Table 2. Pearson correlation among soil properties and sweet corn growth variables

\begin{tabular}{|c|c|c|c|c|c|c|c|c|}
\hline & $\mathrm{MBC}$ & POMC & Exc-Al & Soil pH & P-Bray & Exc K & $\mathrm{PH}$ & SDW \\
\hline TSOC & $0.85 * *$ & $0.21^{\mathrm{ns}}$ & $-0.55^{*}$ & $0.71 * *$ & $0.79 * *$ & $0.72 * *$ & $0.87 * *$ & $0.81 * *$ \\
\hline $\mathrm{MBC}$ & & $0.43^{\mathrm{ns}}$ & $-0.68 * *$ & $0.80 * *$ & $0.70 * *$ & $0.60 *$ & $0.84 * *$ & $0.74 * *$ \\
\hline POMC & & & $-0.66^{*}$ & $0.49^{*}$ & $0.19^{\mathrm{ns}}$ & $-0.16^{\mathrm{ns}}$ & $0.19^{\mathrm{ns}}$ & $0.29^{\mathrm{ns}}$ \\
\hline Exc Al & & & & $-0.92 * *$ & $-0.48^{*}$ & $-0.24^{\mathrm{ns}}$ & $-0.50 *$ & \\
\hline & & & & & & & & $0.60 * *$ \\
\hline Soil pH & & & & & $0.60 * *$ & $0.46 \mathrm{~ns}$ & $0.66^{*}$ & $0.71 * *$ \\
\hline P-Bray & & & & & & $0.86^{* *}$ & $0.87 * *$ & $0.92 * *$ \\
\hline Exc K & & & & & & & $0.71 * *$ & $0.79 * *$ \\
\hline $\mathrm{PH}$ & & & & & & & & $0.82 * *$ \\
\hline
\end{tabular}




\section{Effect of Water Hyacinth Compost on Sweet Corn Growth}

Enhancement of soil quality lead to the improvement of sweet corn growth as indicated by plant height and shoot dry weight. Figures 8 and 9 showed that application of compost linearly increased plant height and shoot dry weight. This result is in agreement with that investigated by Osoro et al. (2014) where water hyacinth compost significantly increased plant height, shoot dry weight and root dry weight of corn. Least prominent increment of plant height was observed in sweet corn grown in Udults and reversal was true for shoot dry weight of sweet corn.

Water hyacinth compost rate of $25 \mathrm{Mg} \mathrm{ha}^{-1}$ enlarged shoot dry weight by $50.10 \%, 45.30 \%$ and $216.89 \%$ for Andepts, Udepts and Udults, respectively in comparison to that control. This might be associated with pronounced reduction of $\mathrm{Al}$ and increase of soil $\mathrm{pH}$ in Udults after application of particular compost, leading to better growth environment. This indicates that sweet corn has high response to water hyacinth compost when grown in Udults.

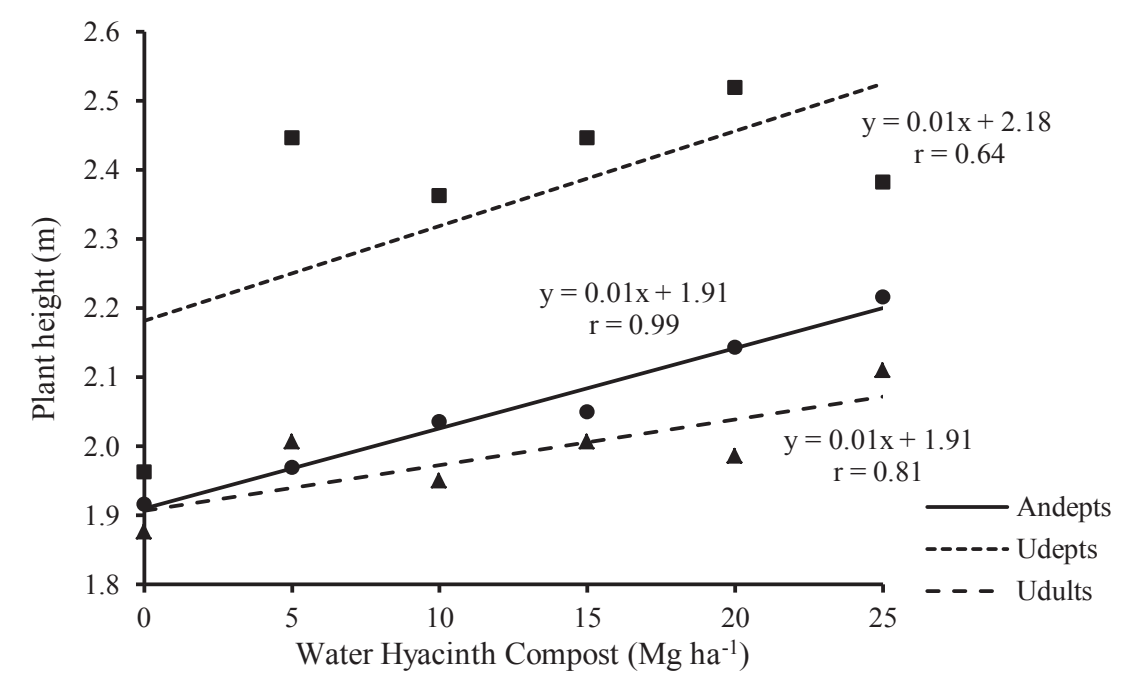

Figure 8. Water hyacinth compost influence on plant height of sweet corn. 
Table 2 also showed that soil available $\mathrm{P}$ was significantly related to sweet corn height and shoot dry weight with coefficient correlation of 0.83 and 9.2, respectively. The correlation suggested that soil available $\mathrm{P}$ highly contributed to sweet corn growth. Total soil organic carbon was also pronouncedly related to plant height and shoot dry weight of sweet corn with coefficient correlation of 0.87 and 0.87 , respectively. Upon mineralization of soil organic matter will release plant nutrients, thereafter available to the plant.

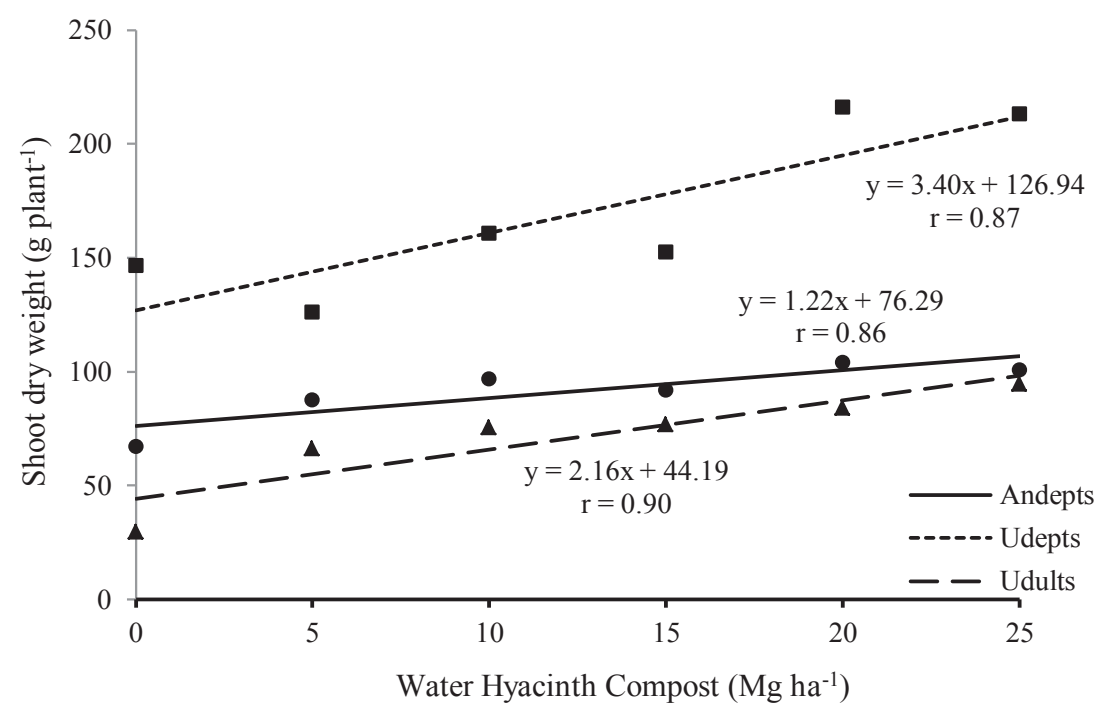

Figure 9. Effect of water hyacinth compost on shoot dry weight

\section{Conclusion}

Application of water hyacinth compost provided distinct increase in soil quality as indicated by enhancement of TSOC, MBC, soil $\mathrm{pH}$, available $\mathrm{P}$, exchangeable $\mathrm{K}$ and reduction of exchangeable Al. Udepts exhibited greatest TSOP, MBC, soil $\mathrm{pH}$, available $\mathrm{P}$, and exchangeable $\mathrm{K}$ while Andepts had highest POMC and least exchangeable Al. Udults had most prominent increase in soil $\mathrm{pH}$ and reduction of exchangeable $\mathrm{Al}$, indicating high response of the soil to application of water hyacinth compost. There was distinct correlation among most soil properties and sweet corn growth variables. The most prominent correlation among soil properties was observed between exchangeable $\mathrm{Al}$ and soil $\mathrm{pH}$ with coefficient correlation of -0.91 , followed by TSOC vxith MRC ( $r=0$ 85) Plant height wara nronnuncedlv related to chont drv 
weight with coefficient correlation of 0.82 . The distinct correlation of soil chemical property and sweet corn growth was found between soil available P, followed by TSOC and shoot dry weight with correlation 0.92 and 0.81 , respectively. This indicates that soil available $\mathrm{P}$ has significant contribution on sweet corn growth.

\section{References}

Adeboye, M. K.A., Bala, A., Osunde, A. O., Uzoma, A. O., Odofin, A. J. and Lawa, B. A. (2011). Assessment of soil quality using soil organic carbon and total nitrogen and microbial properties in tropical agroecosystems. Agricultural Sciences. 2(1): 34-40.

Adijaya, I. N. and Made, R. Y. (2014). Pengaruh pupuk organik terhadap sifat tanah, pertumbuhan dan hasil jagung. Proceeding of National Seminar "Inovasi Teknologi Pertanian Spesifik Lokasi”, Banjarbaru 6-7 August 2014 pp. 299-310 (in Indonesian).

Amighi S. J., Asgari, H., Sheikh, V. B. and Sardo, M. S. (2013). Effects of agroforestry systems on carbon sequestration and improvement soil quality. International Journal of Agriculture: Research and Review 3 (4): 822-828.

Ananyeva, N. D., Susyan, E. A., Ryzhova, I. M., Bocharnikova, E. O., and Stolnikova, E. V. (2009). Microbial biomass carbon and the microbial carbon dioxide production by soddy-podsolic soils in postagrogenic biogeosenoces and in native spruce forest of the southern Taiga (Kostroma Oblast). Eurasian Soil Sci. 42(9): 1029-1037.

Arthur, E., Cornelis, W. and Razzaghi, F. (2012). Compost amendment to sandy soil affects soil properties and greenhouse tomato productivity. Compost Sci. Util. 20(4):215-221.

Baaru, M. W., Mungendi,D. N., Bationa, A., Verchot, L. and Waceke, W. (2007). Soil microbial biomass carbon and nitrogen as influenced by organic and inorganic inputs at Kabete, Kenya. in Advanced in Integrated Soil Fertility in sub Saharan Africa: Challenges and Opportunities. ed. A. Bationo, B. Waswa, J. Kihara, and J. Kimetu. pp. $827-832$.

Butler, T. J., Weindorf, D. C., Han, K. J. and Muir. J. P. (2009). Dairy manure compost quality effects on corn silage and soil properties. Compost Sci. and Utilization 17(1): 18-24.

Cambardella, C.A. and Elliott, E. T. (1992). Particulate soil organic matter changes across a grassland cultivation sequence. Soil Sci. Soc. Am. J., 56: 777-783.

D’Hose, T., Cougnon, M., Vliegher, A., Willekens, K., Bockstaele, E. V. and Reheul, D. (2012). Farm compost application: Effects on crop performance. Compost Sci. Util. 20(1):49-56.

De Varennes, A., Cunha-Queda, C. and Qu, G. (2010). Amendment of an acid mine soil with compost and polyacrylate polymers enhances enzymatic activities but may change the distribution of plant species. Water Air Soil Pollut. 208:91-100.

Hosseinpur, A. R., Kiani, Sh. and Halvaei, M. (2012). Impact of municipal compost on soil phosphorus availability and mineral phosphorus fractions in some calcareous soils. Environmental Earth Sci. 67(1): 91-96.

Ifansyah, H. (2013). Soil pH and solubility of aluminum, iron, and phosphorus in Ultisol: the roles of humic acid. J. Trop. Soil 18(3): 203-208.

Iqua, P. and Huasi, L. (2009). Effect of chicken manure, Tithonia diversifolia and Albizzia spp on maize plant height and dry matter production - Lessons Learnt in the Eastern Highlands of PNG. p. 240-250. Proc. 17th International Farm Management Congress, Bloomington/Normal, Illinois, USA. July 2009. 
Islam, K.R. and Weil, R. R. 2000. Soil quality indicator properties in mid-Atlantic soils as influenced by conservation management. Journal of Soil and Water Conservation 55(1) : 69-78.

Jouquet, E.P., Bloquel, E., Doan, T. T., Ricoy, M., Orange, D., Rumpel, C. and Duc, T. T. (2011). Do compost and vermicompost improve macronutrient retention and plant growth in degraded tropical soils? Compost Sci. Util. 19(1):15-24.

Khan, S. and Sanwar, K. S. (2002). Effect of water hyacinth compost on physical, physicochemical properties of soil and on rice yield. Pakistan J. of Agronomy 1(2-3): 64-64.

Lata, N. and Dubey, V. (2013). The impact of water hyacinth manure on growth attributes and yield in Coriandrum sativum. J. Envrimental Sci. Toxicology and Food Tech. 5(3): 4-7.

Lata, N. and Veenapani. (2011). Response of water hyacinth manure on growth attributes and yield in brassica. juncea. J. Central European Ag. 12(2): 336-343.

Lim, S. S., Kwak, J. H., Lee, S., Lee, D. S., Park, H. J., Hao, X. and Choi, W. J. (2010). Compost type effects on nitrogen leaching from Inceptisol, Ultisol, and Andisol in a column experiment. J. Soil Sediments 10: 1517-1526.

Liu, C. H., Liu, Y., Fan, C. and Kuang, S. Z. (2013). The effect of composted pineapple residue return on soil properties and the growth and yield of pineapple. J. Soil Sci. Plant Nutr. 13(2): 433-444.

Liu, E., Yan, C., Mei, X., Zhang, Y. and Fan, T. (2013). Long-term effect of manure and fertilizer on soil organic carbon pools in dry land farming in Northwest China. Plos one. http://dx.doi.org/10.1371/journal.pone.0056536, downloaded 7 October 2016.

Mankolo, R., Reddy, C., Senwo, Z., Nyakatawa, E. and Sajjala, S. (2012). Soil biochemical change induced by poultry litter application and conservation tillage under cotton production system. Agronomy 2:187-198.

Mashavira, M., Chitata, T., Mhindu, R. L., Muzemu, S., Kopenzi, A. and Majeru, P. (2015). The effect of water hyacinth (Eichcornia crassipes) compost on tomato (Lycopersicon esculentum) growth attributes, yield potential and heavy metal levels. Am. J. Plant Sci. 6: 545-553.

Mashavira, M., Mhindu, R. L., Muzemu, S., Chitata, T. and Manjeru, P. (2014). The effect of water hyacinth (Eichornia crasspes, L.) compost application on heavy metal concentration and agronomic performance of cabbage. Midlands State University J. of Sci. Ag and Tech. 5(1): 121-132.

Muktamar, Z., Aneri, D. and Suprapto. (1998). Aplikasi asam sitrat dan oksalat untuk mengurangi keracunan alumunium pada tanaman kedelai. J. Akta Agrosia 2(1): $22-27$ (in Indonesian)

Muktamar, Z., Candra, I. and Chozin, M. (1998). Pengurangan keracunan alumunium pada tanaman kedelai melalui pemberian pupuk kandang sapi pada tanah asam. J. Penelitian UNIB No. 11: 39-45 (in Indonesian).

Muktamar, Z., Fahrurrozi, Dwatmadji, Setyowati, N., Sudjatmiko, S. and Chozin, M. (2016). Selected macro nutrients uptake by sweet corn under different rates of liquid organic fertilizer in closed agriculture system. IJASEIT 6(2): 258-361.

Muktamar, Z., Hasibuan, S. Y. K., Suryati, D. and Setyowati, N. (2015). Column study of nitrate downward movement and selected soil chemical properties' changes in mine spoiled soil as influenced by liquid organic fertilizer. J. Ag. Tech. 11(8): 2017-2027.

Muktamar, Z., Setyowati, N. and Putri, D. (2016). Reduction of synthetic fertilizer for sustainable agriculture: Influence of organic and nitrogen fertilizer combination on growth and yield of green mustard. IJASEIT 6(3): 361-364. 
Ochiai, N., Powelson, M. L., Crowe, I. J. and Dick, R. P. (2008). Green manure effects on soil quality in relation to suppression of verticillium wilt of potato. Biol. Fertl. Soils 44:1013-1023.

Opala, P. A., Okalebo, J. R. and Othieno, C. O. (2012). Effect of organic and inorganic material on soil acidity and phosphorus availability in a soil incubation study. ISRN Agronomy vol. 2012. Article ID 597216 10p. doi:10.5402//2012/597216.

Osoro, N., Muoma, J. O., Amoding, O., Mukaminega, D., Muthini, M., Ombori, O. and Maingi, J. M. (2014). Effects of water hyacinth (Eichornia crassipes[mart.] solms) compost on growth and yield parameters of maize (Zea mays). British J. of Applied Sci. Tech. 4(4):617-633.

Pujiyanto. (2007). Pemanfaatan kulit buah kopi dan bahan mineral sebagai amelioran tanah alami. pelita perkebunan. 23 (2) : 159-172, (in Indonesian).

Setyowati, N., Muktamar, Z., Oktiasa, S. and Ganefianti, D.W. (2014). Growth and yield of chili pepper under different time application of wedelia (Wedelia trilobata) and siam weed (Chromolaena odorata) organic fertilizers. IJASEIT 4(6): 13-16.

Setyowati, N., Muktamar, Z. and Puspitasari, I. (2015). Weed based organic fertilizer to reduce application of synthetic fertilizer in mustard (Brassica sinensis L.). J. Ag. Tech. 11(8): 1677-1683.

Setyowati, N., Nurjannah, U. and Haryanti, D.( 2008). Gulma tusuk konde (Wedelia trilobata) dan kirinyu (Chromolaena orodata) sebagai pupuk organik pada sawi. Akta Agrosia 2(1): 47-56. (in Indonesian).

Spark, D.L. 2003. Environmental Soil Chemistry. Second ed. Academic Press. New York. USA.

Suntoro, S., Handayanto, E. and Soemarno. (2001). Penggunaan eceng gondok (Eichornia crassipes) untuk meningkatkan ketersediaan $\mathrm{P}, \mathrm{K}, \mathrm{Ca}$, dan $\mathrm{Mg}$ Ilmu Pertanian. Agrivita 23 (1): 20-26 (in Indonesian).

Suntoro, S., Syekhfani, Hardayanto, E. and Soemarno.(2001). Penggunaan bahan pangkas kriyu (Cromalaena odorata) untuk meningkatkan ketersediaan P. K. Ca. dan $\mathrm{Mg}$ pada Oxic Dystrudept di Jumapolo Karangayar Jawa Tengah. Agrivita 23(1) (in Indonesian Language).

Valarini, P. J., Curaqueo, G., Seguel, A., Manzano, K., Rubio, R., Cornejo, P. and Borie, F. (2009).Effect of compost application on some properties of a volcanic soil from South Chile. Chilean J. of Ag. Research 69(3): 416-425.

Vidya, S. and Girish, L. (2014). Water hyacinth as a green manure for organic farming. Impact J. 2(6): 65-72.

Wahyudi, I., Hardayanto, E., Syekhfani, and Utomo, W. H. (2010). Humic and fulvic acids of gliricidia and tithonia composts for alumunium detoxification in an Ultisol. Agrivita 32(3): 216-224.

Winarso, S., Handayanto, E. and Taufiq, E. (2010). Aluminum detoxification by humic substance extracted from compost of organic wastes. J. Trop. Soil 15(1): 19-24. 
